\title{
Coastal Change During Hurricane Dennis 2005
}

Hurricane Dennis made landfall as a Category 3 storm on Santa Rosa Island in the Florida Panhandle on July 10, 2005. Exposed to some of the strongest winds, Santa Rosa Island suffered erosion, as well as severe overwash. A storm surge of $2 \mathrm{~m}$ was recorded near Navarre Beach.

The U.S. Geological Survey (USGS) and U.S. Army Corps of Engineers (USACE) are collaborating in a research project investigating coastal change that occurred as a result of Hurricane Dennis. The USGS acquired still oblique aerial photography both before and after hurricane landfall to better understand the impacts of extreme storms on coastal environments. On Tuesday, July 12 , 2005, scientists conducted an aerial photographic survey of Santa Rosa Island, Florida, that was impacted by Hurricane Dennis.

The photographs were compared to pre-Dennis photographs taken in July 2001 and after the landfall of Hurricane Ivan in September 2004 to illustrate extreme coastal change. On Santa Rosa Island, the storm eroded dunes and beaches, and overwashed roads. In Navarre Beach, parking lots and roads were covered with sand and dune walkovers damaged or destroyed.

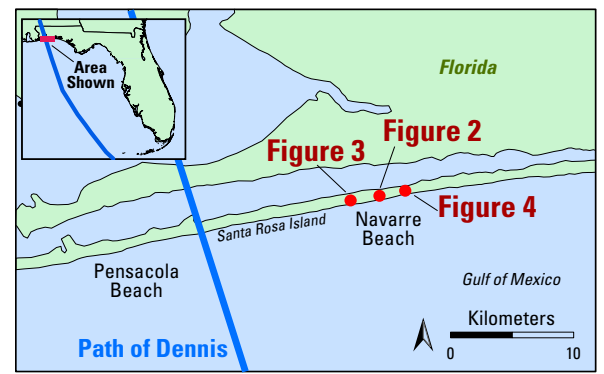

Figure 1. Map showing track of Hurricane Dennis in 2005 across Santa Rosa Island, Florida.

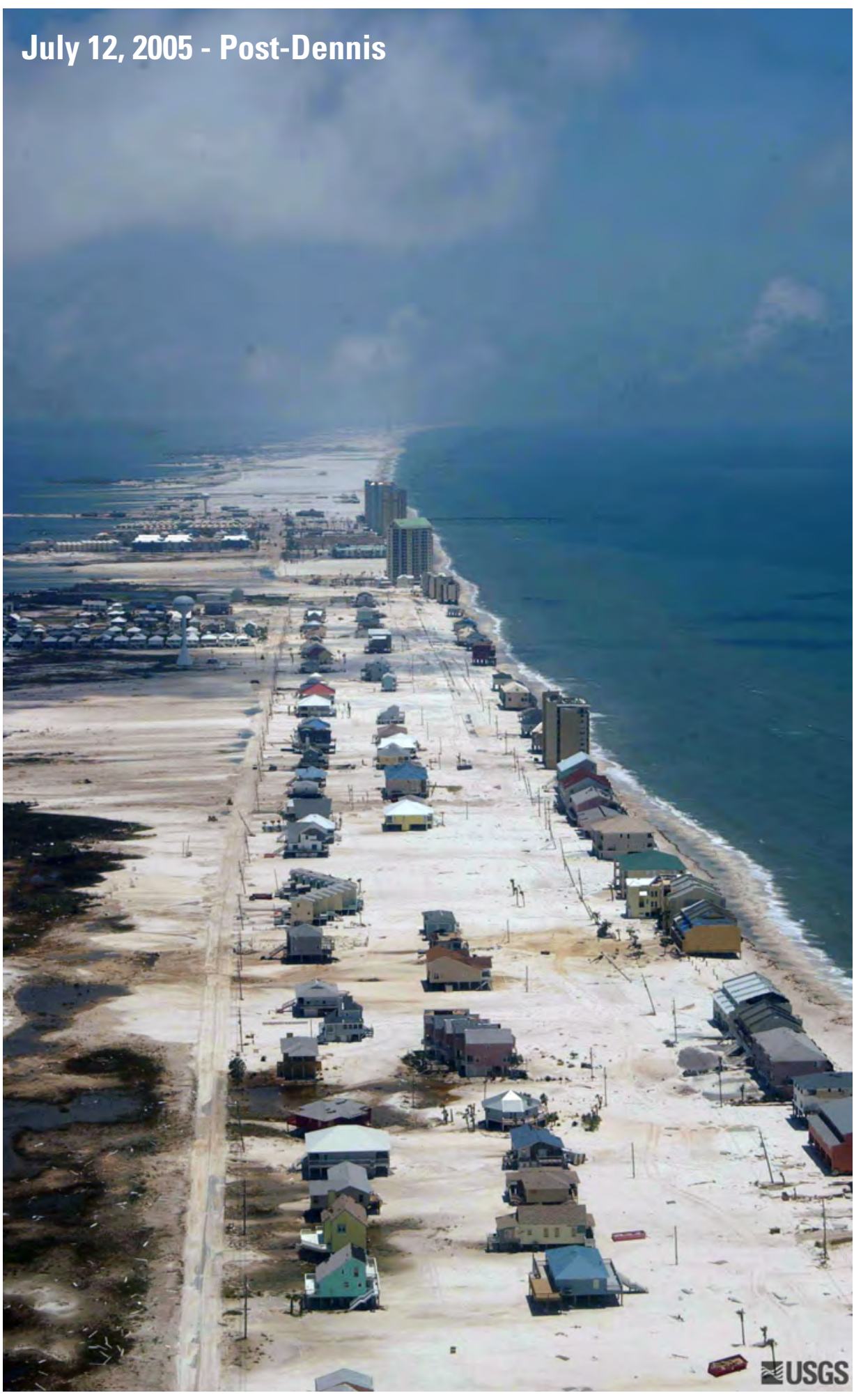

Figure 2. Santa Rosa Island, Florida, suffered severe erosion and overwash during Hurricane Dennis. Looking east, the magnitude of the overwash is evident. Overwash fans extend northward across the island, covering roads with sand eroded from the beach and dunes. In some cases, the overwash extends into the back bay. 

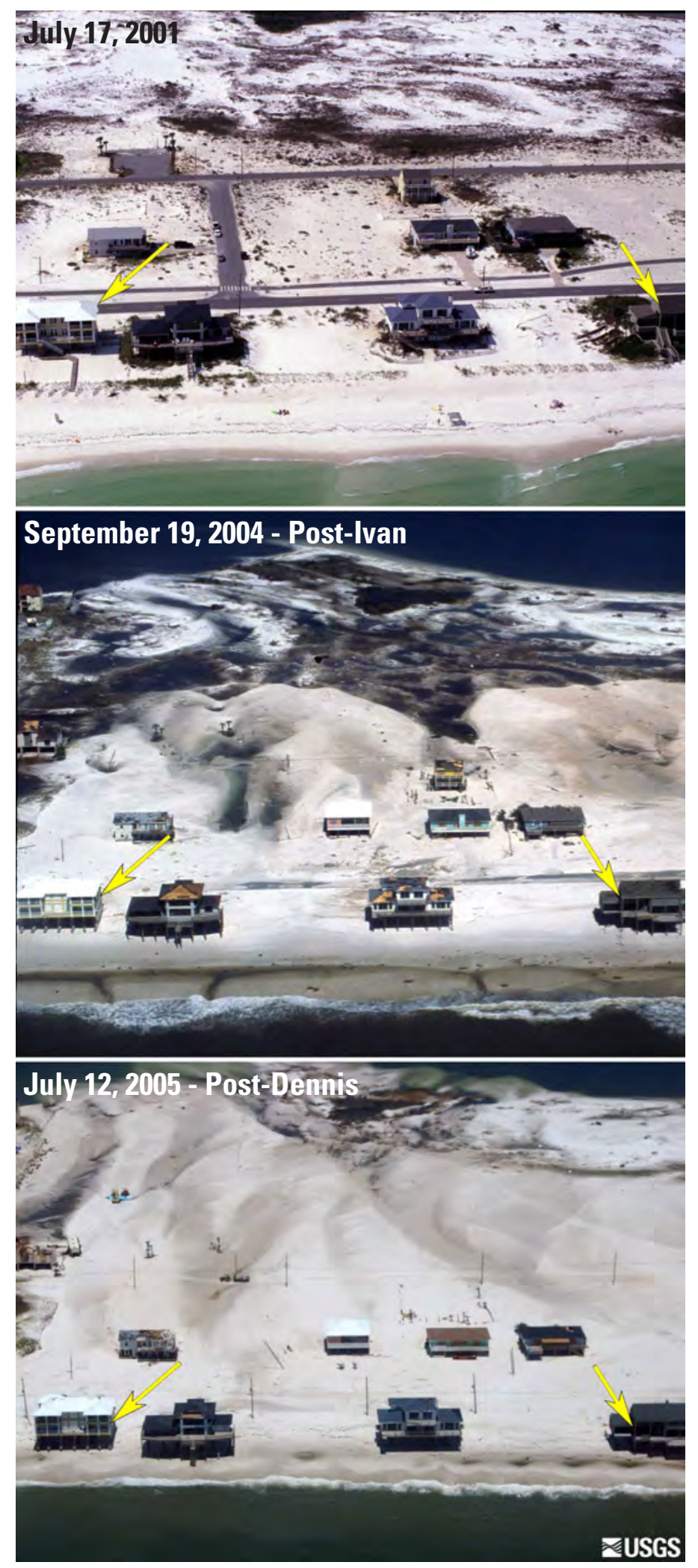

Figure 3. Navarre Beach, Florida. On this part of Navarre Beach, overwash deposits from Hurricane Dennis extend farther landward than overwash deposits from Hurricane Ivan. Deposits from both storms covered the two coast-parallel roads. (Arrows in all images point to the same features.)
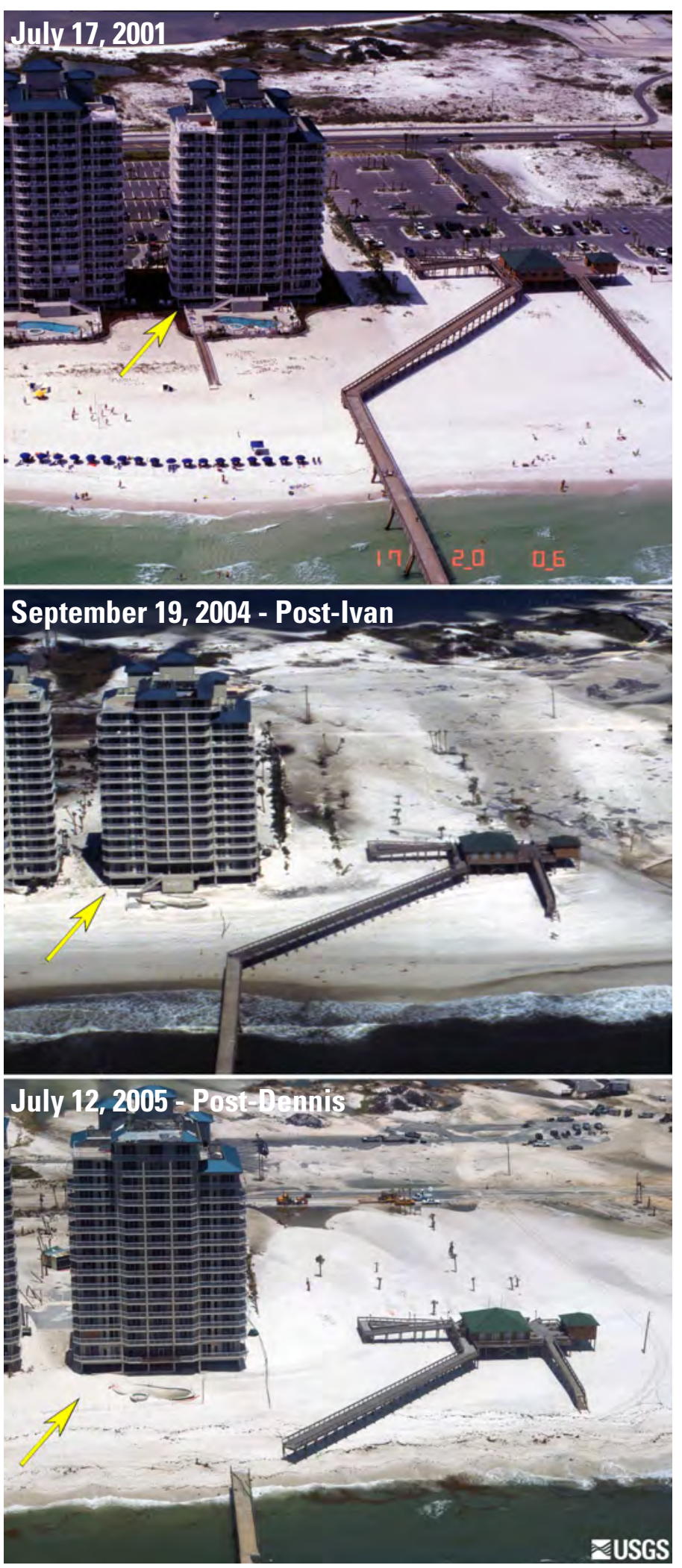

Figure 4. Navarre Beach, Florida. Overwash during Hurricane Ivan covers the parking lot and road with sand. Overwash from Hurricane Dennis covers the parking lot with sand, but does not extend as far inland as did the overwash during Hurricane Ivan. A section of the pier is missing following landfall of Hurricane Dennis. (Arrows in all images point to the same features.) 